\title{
Housing and Health - Proposal of a Methodology for Risk Assessment for Occupants
}

\author{
Marisa Monteiro $^{1}$, João C. G. Lanzinha ${ }^{2}$, and M. Ramiro Pastorinho ${ }^{3}$ \\ 1. LABSED - Housing Health Lab, Faculty of Engineering, Universidade da Beira Interior, Covilhã, Portugal \\ 2. LABSED - Housing Health Lab, C-MADE, Faculty of Engineering, Universidade da Beira Interior, Covilhã, Portugal \\ 3. Department of Medical Sciences, Faculty of Health Sciences, Universidade da Beira Interior, Covilhã, Portugal
}

\begin{abstract}
Nowadays people spend a large amount of their time inside their homes. However, prevailing indoor conditions in terms of comfort and environmental quality could present health challenges to the inhabitants. Therefore, a good indoor environmental quality is essential, since in addition to the risk parameters present in indoor air, the relative humidity and the dangers inherent in housing, the health and human well-being can also be affected by high or low temperatures inside their homes. It is necessary that during the use of the building the sources of risk are identified, in order to prevent them and to promote the health of its occupants. In this context, this paper intends to describe a proposal to create a methodology that provides a risk assessment for the occupants of a dwelling, with certain technical features and also delivers some information about a pilot campaign that was launched by an interdisciplinary team from University of Beira Interior in order to collect and analyze some indoor environment data from 6 households representing 6 different decades.
\end{abstract}

Key words: housing, health, methodology, indoor comfort, climate change

\section{Introduction}

The impact of the quality of indoor air on the health and welfare of people who use or work indoors has been the subject of different research in the area of public health at least since 1970. Today, people spend much of their time indoor, inside their homes, at work or at school. According to the World Health Organization (WHO), the indoor air quality of buildings is critical to the health and well-being of its occupants, since exposure to risk agents present in many indoor spaces can cause adverse health effects such as respiratory diseases, allergies and diseases of the nervous system. [1].

These risks can be attributed to domestic air pollution, extreme temperatures, pests and infestations,

Corresponding author: Marisa Monteiro, Master in Civil Engineering, Ph.D. Student, research areas/interests: housing and health. E-mail: m-r-monteiro@hotmail.com. noise, to infectious diseases carried by air, water contamination, mold, internal injuries and poisoning and can also cause effects on mental health of the occupants [2].

On the other hand, climatic factors show a high importance on human health and welfare, there is a scientific consensus that the climate is changing. If current trends continue (as the temperature increases, the average sea level arises and extreme weather events are more frequent), it may lead to serious impacts on human health. In addition to the risk parameters present in the indoor air of buildings, health and well-being of its occupants can also be affected by indoor thermal fluctuation and by relative humidity. Whenever there are waves of cold or heat, high numbers of deaths are recorded [3].

\section{Goals}

In the research of the conditions of indoor comfort 
and environmental quality in residential accommodation and its possible effects for the occupants, we developed an experimental measurement campaign on characterization parameters of indoor environments carried out by a multidisciplinary team at the University of Beira Interior (UBI).

As one of the main objectives of the study was to develop recommendations on the constructive characteristics, equipment, coating materials and conditions for use of living spaces that can reduce the risk to the health of occupants, this campaign included the evaluation for sixty days around six dwellings on six different construction decades (1960-2010). Weekly measurements were made and samples were taken in representative spaces of the main occupational activities of the residents inside its housing, namely bedrooms, living rooms, kitchens and toilets.

\section{Experimental Campaign}

\subsection{Dwellings in Study}

The dwellings are located in the area of the city of Covilhã, which is located on the southeastern slope of the Serra da Estrela, Portugal. The city of Covilhã is municipality and has an area of $550 \mathrm{~km}^{2}$, and its total population, according to the census in 2011, estimated at around 52,000 inhabitants [4, 5].

In Table 1 are identified dwellings, their type, household composition, location and year of construction.

Table 1 Dwellings characterization.

\begin{tabular}{|c|c|c|c|}
\hline Dwelling ID & Household & Type & $\begin{array}{c}\text { Construction } \\
\text { decade }\end{array}$ \\
\hline House A & 3 & $\begin{array}{c}\text { Apartment-3 } \\
\text { bedrooms }\end{array}$ & 1960 \\
\hline House B & 2 & $\begin{array}{c}\text { Apartment-3 } \\
\text { bedrooms }\end{array}$ & 1970 \\
\hline House C & 2 & $\begin{array}{c}\text { Apartment-3 } \\
\text { bedrooms }\end{array}$ & 1980 \\
\hline House D & 3 & $\begin{array}{c}\text { Detached house-4 } \\
\text { bedrooms }\end{array}$ & 1990 \\
\hline House E & 4 & $\begin{array}{c}\text { Detached house-3 } \\
\text { bedrooms }\end{array}$ & 2000 \\
\hline House F & 1 & $\begin{array}{c}\text { Apartment-3 } \\
\text { bedrooms }\end{array}$ & 2010 \\
\hline
\end{tabular}

Under this multidisciplinary project were evaluated several different parameters included assessment of indoor air quality, evaluation of environmental contaminants and evaluation of the health status of residents.

In the first phase, before starting the first measurement registration campaign, after selection of housing and obtaining the consent of the respective residents, the following activities were also developed:

- $\quad$ Visit to the houses;

- $\quad$ Residents survey;

- Survey of all the technical characteristics of the target housing by completing an inspection form (registration identification and general information of the house in the study, information building as on interior spaces of houses, marked to make the measurements and evaluation outside the shown in Table 2);

- Household Survey.

In this work we present the parameters for assessing the indoor air quality.

\subsection{Parameters in Study}

The parameters and frequency of measurements are presented in Table 3.

Table 2 Logged information in inspecting form.

\begin{tabular}{|c|c|c|}
\hline $\begin{array}{c}\text { General } \\
\text { information }\end{array}$ & Indoor assessment & $\begin{array}{c}\text { Outdoor } \\
\text { assessment }\end{array}$ \\
\hline $\begin{array}{l}\text { Name of the } \\
\text { technical } \\
\text { inspector; } \\
\text { Data relating to } \\
\text { residents; } \\
\text { Data relating to } \\
\text { housing; } \\
\text { Date concerning } \\
\text { the building; } \\
\text { Heating type; } \\
\text { Cleaning and } \\
\text { maintenance } \\
\text { supplies; } \\
\text { IT systems; } \\
\text { Pets. }\end{array}$ & $\begin{array}{l}\text { Walls (finishing and } \\
\text { coating materials); } \\
\text { Ceiling (finishing and } \\
\text { coating materials); } \\
\text { Floor (finishing and } \\
\text { coating materials); } \\
\text { Glazed areas (size, type } \\
\text { of glass, window frames } \\
\text { and shading); } \\
\text { Doors (size, type of door, } \\
\text { window frames); } \\
\text { Furniture (fixed, } \\
\text { removable, materials and } \\
\text { quantities); } \\
\text { Heating (electric, oil, } \\
\text { gas, water, etc.); } \\
\text { Plants (number of vessels } \\
\text { species); } \\
\text { Anomalies detected; } \\
\text { Photographic record. }\end{array}$ & $\begin{array}{l}\text { Kind of outdoor } \\
\text { walls; } \\
\text { Surrounding } \\
\text { environment. }\end{array}$ \\
\hline
\end{tabular}


Table 3 Parameters and measurement.

\begin{tabular}{|c|c|c|c|}
\hline \multirow{2}{*}{ Parameters } & \multicolumn{3}{|c|}{ Measurement } \\
\cline { 2 - 4 } & Permanent & Weekly & $\begin{array}{c}\text { Collect } \\
\text { after 60 } \\
\text { days }\end{array}$ \\
\hline Indoor Temperature & $\mathrm{x}$ & $\mathrm{x}$ & \\
\hline Relative humidity & $\mathrm{x}$ & $\mathrm{x}$ & \\
\hline $\begin{array}{c}\text { Formaldehyde } \\
\text { (HCHO) }\end{array}$ & & $\mathrm{x}$ & \\
\hline $\begin{array}{c}\text { Carbon monoxide } \\
\text { (CO) }\end{array}$ & $\mathrm{x}$ & $\mathrm{x}$ & \\
\hline $\begin{array}{c}\text { Carbon dioxide } \\
\text { (CO })_{2}\end{array}$ & & $\mathrm{x}$ & \\
\hline $\begin{array}{c}\text { Volatile organic } \\
\text { compounds (VOC) }\end{array}$ & & $\mathrm{x}$ & \\
\hline $\begin{array}{c}\text { Organotins (1) } \\
\text { Fungi (1) }\end{array}$ & & & $\mathrm{x}$ \\
\hline
\end{tabular}

(1) Materials collected in vacuum bags and passive samplers.

In each dwelling was recorded the indoor temperature, relative humidity, formaldehyde, carbon monoxide, carbon dioxide and volatile organic compounds.

\subsection{Equipment and Conditions of Weekly Measurement}

The data relating to physical parameters and volatile organic compounds was performed using the measurement equipment available in LABSED Laboratory for Health in Buildings of UBI Medical (University of Beira Interior), located in Covilhã, Portugal.

All equipment was properly calibrated and before each measurement was performed the respective stabilization of the equipment. Were recorded all aspects or events considered out of the "normality" and which may affect the measurements (opened windows, people in space, electronic equipment connected, etc.). The measurements made were recorded in the inspection form prepared for that purpose. The external environmental conditions were obtained from the records of the meteorological station of the University of Beira Interior, located in the same urban area of the buildings in the study, approximately at 680 meters level.
To measure the indoor temperature, relative humidity, total volatile organic compounds and carbon dioxide the thermo-anemometers used were Velocicalc TSI - Models 9565 and 7545 (Fig. 1).

For the monitoring of formaldehyde was used a portable monitor for measuring instantaneous, formaldehyde meter HTV model, brand PPM (Fig.).

The indoor temperature, relative humidity and carbon monoxide were monitored continuously with digital data loggers during 60 days in some of the main spaces of houses.

\section{First Campaign Measurements- Examples}

In Portugal, since 2006, there is legislation that defines the maximum reference concentrations of pollutants inside buildings. To undertake an assessment of indoor air quality, concentrations of all

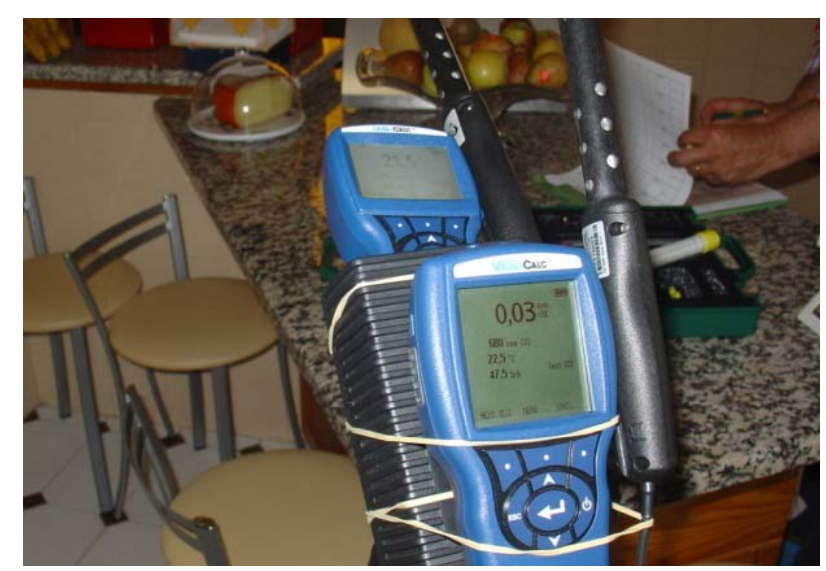

Fig. 1 Velocicalc TSI model 9565 and model 7545.

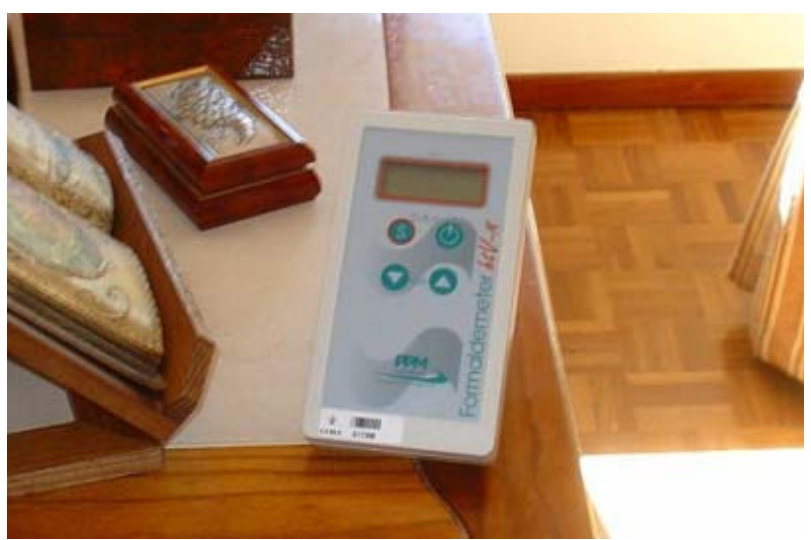

Fig. 2 Formaldehyde meter PPM - HTV-m. 
pollutants have to be measured and compared with the maximum concentrations of reference laid down in Annex VII of Decree-Law No. 79/2006 of April 4 [6].

Next, they will be presented a few examples of measurements taken in the first measurement campaign. These results will be compared with the values of national and international legislation.

\subsection{Indoor Temperature - Kitchens}

In an attempt to understand the influence of the external environment in the indoor environment, there has been registered the temperature of the inside air and the outside air in each of the measuring campaigns. In the next Figure we have the average indoor/outdoor temperatures and the reference value, according to ISO 7730 and Housing health and safety rating system (HHSRS).

According to Decree-Law 118/2013 of 20 August [7], the temperature aiming thermal comfort should be $25^{\circ} \mathrm{C}$ in summer and $18^{\circ} \mathrm{C}$ in the heating period (winter). Through the analysis of the data in Fig. 3, is verified that only about $33 \%$ of the measurements are within the range of recommended values.

Through analysis of the chart (Fig. 3), we can see that during the 9 weeks, the House A (1970) always has the highest indoor air temperature and D (2000) has the lowest temperature.

\subsection{Carbon Monoxide (CO) - Kitchens}

Through the Fig. 4 can be seen that carbon monoxide concentrations are less than the maximum reference value. However, it appears that the house has slightly

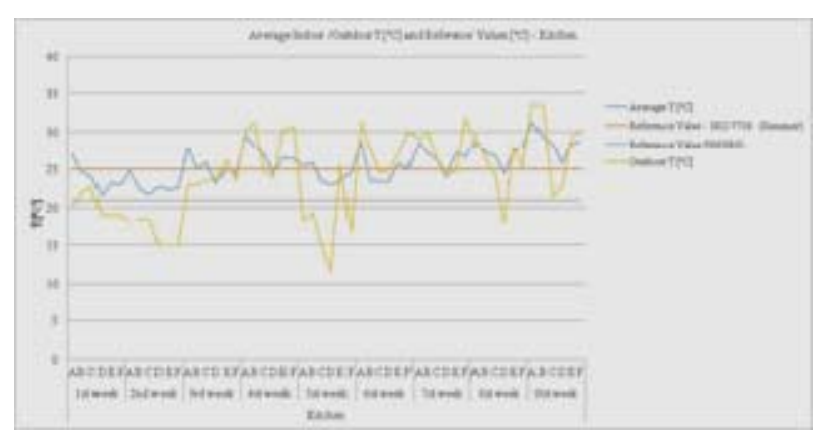

Fig. 3 Average indoor/outdoor $\mathrm{T}\left({ }^{\circ} \mathrm{C}\right)$ and reference values (Kitchens) — during 9 weeks.

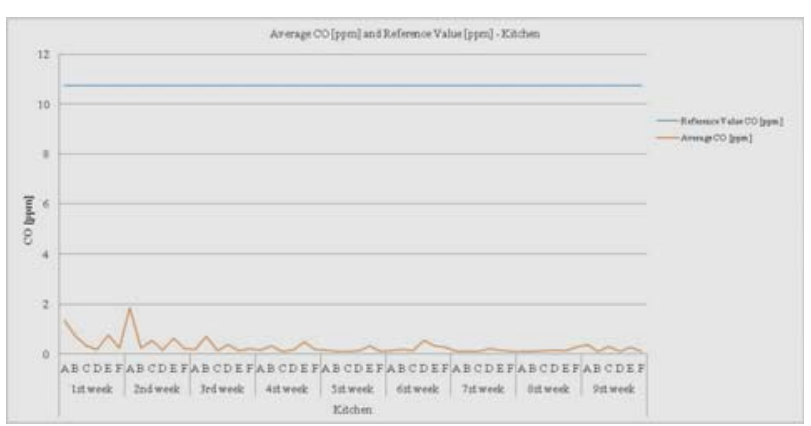

Fig. 4 Average CO and reference value (Kitchens) during 9 weeks.

higher concentrations, which may be related to the stove and/or other burning appliances.

\subsection{Carbon Dioxide $\left(\mathrm{CO}_{2}\right)$ - Kitchens}

Carbon dioxide concentrations in the kitchens of dwellings in the study are presented in Fig. 5.

In the Fig. 5, you can see that the House B has a higher concentration than other homes. At the 4 th week, the average concentration was almost 1200 ppm, and the maximum reference value is $984 \mathrm{ppm}$. Besides other sources, carbon dioxide is also produced in the combustion of gas appliances. So, in this case, it's important to control the concentrations of $\mathrm{CO}_{2}$.

\subsection{Formaldehyde - Kitchens}

By analysing Fig. 6 it's seen that in all of the dwellings are registered average values (all rooms) exceeding the reference value $(0.08 \mathrm{ppm}$ - Decree-Law No. 79/2006 of April 4 [6]). The maximum average concentrations were registered at House $\mathrm{C}$ with the value of $0.17 \mathrm{ppm}$ and $0.24 \mathrm{ppm}$ in House D. At the same time of the measurement, in the room in study,

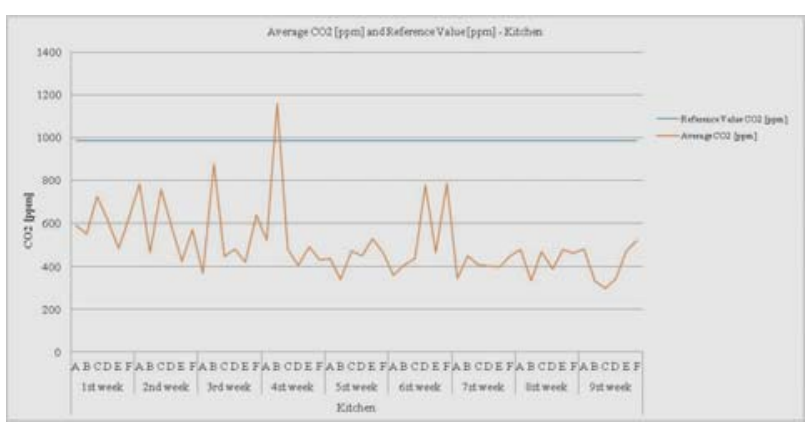

Fig. 5 Average $\mathrm{CO}_{2}$ and reference value (Kitchens) during 9 weeks. 


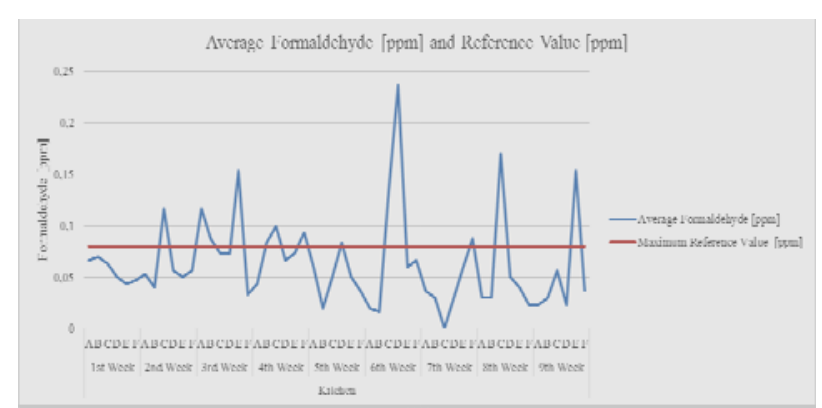

Fig. 6 Formaldehyde - Average Values (Kitchen).

were being used cleaning products. These products, at a later stage of this study, will be analysed and formaldehyde measurements will be compared, in order to draw conclusions about the impact on indoor air caused by the use of certain cleaning products.

\section{Conclusion}

In this work we present some measurements made in the first campaign (summer season). A new campaign was made this winter, in order to compare the concentrations and evaluate the behaviour of dwellings, and these data will be further processed. It will also be performed the analysis of other parameters that can affect human health (heavy materials, fungi, etc.).

Beyond this, before starting this research, they were held medical appointments to all residents, and taken samples of organic materials for analysis (nails, hair, urine, etc.).

In this way, it is intended with this investigation $[8,9]$ to get a broader view of potential risks to the occupants of the dwellings.

The ultimate goal is to relate the results with the different decades of construction and coating materials, to propose some recommendations for residents, and create an Assessment Methodology, applicable to Portuguese buildings.

\section{References}

[1] WHO, The right to healthy indoor air — Report on WHO Meeting, Bilthoven, The Netherlands, 15-17 May, 2000.

[2] Health Effects of Climate Change in the UK 2012 Current evidence, recommendations and research gaps, European Centre for Environment and Human Health Health Protection Agency, University of Exeter Medical School, United Kingdom, 2012.

[3] WHO, accessed 05/07/2015, available online at: http://www.who.int/mediacentre/factsheets/fs266/en/.

[4] Município da Covilhã, accessed 07/07/2015, available online at: http://www.cm-covilha.pt/simples/?f=2401.

[5] Pordata, accessed 07/07/2015, available online at: http://www.pordata.pt/Municipios/Quadro+Resumo/Covil h\%C3\%A3+(Munic\%C3\%ADpio)-6503.

[6] Decreto-Lei 79/2006 de 4 de Abril, Regulamento dos Sistemas Energéticos de Climatização em Edifícios, 2006.

[7] DL118/2013 de 20 de agosto, Ministério da Economia e do Emprego - Diário da República, 1. ${ }^{\text {a }}$ série — N. ${ }^{\circ}$ 159, 20 de agosto de 2013.

[8] M. Monteiro, A. C. A. Sousa, M. Ramiro Pastorinho, J. C. Lanzinha and M. Nepomuceno, Projeto 6.60.6 - campanha experimental, in: Proceedings of ICEUBI2015 International Conference on Engineering UBI2015 “Engineering for Society”; UBI - Universidade da Beira Interior, Serviços Gráficos, Faculty of Engineering, Universityof Beira Interior, Covilhã - Portugal, 2-4 Dec 2015.

[9] M. Marisa and J. C. Lanzinha, Proposta de metodologia para avaliação de riscos à saúde dos ocupantes do parque habitacional português, in: Proceedings of IV CIRMARE 2015 - IV Congresso Internacional na Recuperação, Manutenção e Restauração de Edifícios, UFRJ Universidade Federal do Rio de Janeiro, Rio de Janeiro, Brazil, 8-10 Sep. 2015. 